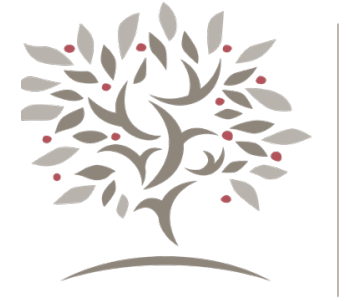

\title{
Integrating the Ignatian Pedagogical Paradigm with Buddhist-Inspired Compassion Meditation
}

\author{
Gloria I-Ling Chien \\ Gonzaga University
}

\begin{abstract}
A B S TRACT
While Ignatian pedagogy is distinctive in Jesuit education, scholarly attention to its applications is scanty. This article demonstrates the relevance of the Ignatian Pedagogical Paradigm (IPP) to compassion cultivation by showing how it integrates into a Buddhist-inspired contemplation program, Cognitively-Based Compassion Training ${ }^{\circledR}(\mathrm{CBCT} \circledast)$. Using a case study of a CBCT ${ }^{\circledR}$ course at a Jesuit University aimed at developing students' "whole person" and ethical discernment, this research analyzes how CBCT® works with the IPP's five elements: context, experience, reflection, action, and evaluation. This study evaluates changes in participant emotional well-being and ethical concerns by employing psychological measurements such as the Compassionate Love for Humanity Scale. The discussion concludes by elucidating how I have adapted this integrative pedagogical method to teach an undergraduate credited course, Buddhist Meditation and Practice. Broadly, this study contributes to a larger conversation about how educators can create an environment that supports both cognitive and affective learning.
\end{abstract}

\section{KEYWORDS}

Jesuit higher education, Ignatian Pedagogical Paradigm, Cognitively-Based Compassion Training®, Buddhist-inspired contemplation, compassion meditation, character development

\section{Introduction}

Mainly derived from Ignatius of Loyola's (1491-1556) Spiritual Exercises, the Ignatian Pedagogical Paradigm (IPP), developed by the International Commission on the Apostolate of Jesuit Education (ICAJE), defines Jesuit education. ${ }^{1}$ In addition to fostering academic excellence, the IPP attempts to form students as "persons of competence, conscience, and compassion" (ICAJE 1993, 249). ${ }^{2}$ A course which aims to cultivate students' compassionate character therefore fulfills this educational goal. To create such a course, which also tied to my research agenda

1 I am grateful for the funding from the Office of the Dean of the College of Arts and Sciences, and from the Center for Teaching and Advising at my institution to support my teaching project on Cognitively-Based Compassion Training ${ }^{\circledR}$.

2 For a succinct investigation of the IPP's relationship with the Spiritual Exercises, see DeFeo (2009, 46-53). 
on Tibetan Buddhist lojong (Tibetan blo sbyong, or “mind-training,") teaching (Chien 2016), I led Cognitively-Based Compassion Training ${ }^{\circledR}(\text { CBCT } ®)^{3}$ in the spring of 2018 at my institution as a ten-week, noncredit course. Surprisingly, I found that CBCT's learning model aligned with the IPP. This article analyzes how I bridged the pedagogical approaches from the IPP and CBCT to create a whole person (cura personalis) learning environment for ethical character formation. I will discuss the outcome of my course goals and conclude by elucidating how I have adapted this integrative method to teach my undergraduate credited Buddhist Meditation and Practice course. Broadly, this study contributes to a larger conversation about how educators create an effective learning environment by familiarizing themselves with specific pedagogical approaches (Gin and Hearn 2019).

\section{Background and Purpose}

My course aimed to widen participants' ethical concerns through CBCT's six contemplation modules, in which students trained skills in attention stability, self-compassion, impartiality, gratitude, and engaged compassion. ${ }^{4} \mathrm{I}$ conducted this project to support both the university's mission to cultivate compassionate leaders and the Jesuit educational goal of caring for the whole person. In cooperation with my colleagues, I recruited students from my Buddhism course and from other departments. The students enrolled had various majors and most of them were juniors and seniors. Eighteen students (eleven females and seven males) completed the class, attending an average of eight out of ten ninety-minute classes.

CBCT's emphasis on character formation parallels the IPP's concept of developing students through "a way of proceeding" that includes five elements: context, experience, reflection, action, and evaluation. First, teachers adapt their methods to individual students' contexts. Then, teachers adopt strategies to encourage learning experiences that include both cognitive and affective domains. Third, students reflect on the new insights their experiences created. Fourth, these insights ideally inspire them to take action, which can be a change in perspective or a concrete activity. Throughout these four elements, teachers evaluate the progression in their students. The IPP can be applied to any discipline that endeavors to promote academic excellence (Nowacek and Mountin 2012) or to emphasize character development. The following analysis shows how I integrated the IPP with my CBCT teaching.

\section{Bridging the IPP and CBCT}

My teaching project attempted to enact CBCT's three levels of learning. I addressed the first level of intellectual understanding through presentations of $\mathrm{CBCT}$ tenets and scientific research on CBCT. ${ }^{5}$ I led meditation practice to foster the second level, intuitive realization. Ideally, the students would then attain the third level, embodying a compassionate character. CBCT's three-step heuristic strategy endeavors to shift participants' habitual pathways of thinking and prepare them for behavioral changes. This goal correlates with ICAJE's claim that the IPP's learning model focuses on transforming students' habitual thought patterns $(1993,245)$. Outside of class meetings, the students followed my weekly meditation audio recording, kept a meditation log, and posted comments in our Facebook group. Their records document that they practiced $\mathrm{CBCT} 3.2$ times per week, averaging a total 7.63 hours of meditation time, which is 53 percent of the instructed amount.

The first IPP element, context, advises educators to adapt their teaching to students' own life situations and larger environment (ICAJE 1993, 380-382). To apply this principle, I paid attention to potential triggers. For example, those who have survived traumatic experiences may find focusing on breathing disturbing. To avoid this potential problem, I gave my students options, such as counting numbers in their mind or keeping their eyes open and trained on an object. Being

\footnotetext{
3 CBCT $®$ is a contemplation program inspired by lojong practice and is led by Emory University's Center for Contemplative Science and Compassion-Based Ethics (CCSCBE), see Emory University (2020 a) CBCT ${ }^{8}$ was created by Dr. Lobsang Negi, a leading figure at the former Emory-Tibet Partnership. The 14 th Dalai Lama inaugurated the Emory-Tibet Partnership in 1998. It was later merged with CCSCBE. For more information, see Emory University (2020 b).

4 CBCT®'s sequential contemplation includes a foundation practice and six modules. The foundation trains participants to recall an experience during which they felt supported and cared for. Modules I and II aim to help participants cultivate mental stability with a focus on breathing and nonjudgmental observation of their feelings and thoughts. From Modules III to VI, practitioners learn analytical meditation to reflect on concepts related to self-compassion, common humanity, gratitude, and compassion. For more information, see Negi (2017).

5 For the relevant research on $\mathrm{CBCT} \circledast$ in psychology and neuroscience, see the bibliography.
} 
aware of potential sensitivities is always important for educators; it is crucial in a meditation course because students may experience both positive and negative emotions. ${ }^{6} \mathrm{I}$ also guided students to be aware of their own contexts. I coached them to investigate how their habits hindered the execution of their plans to practice meditation.

The second IPP element, experience, encourages experiential learning to engage the equally important affective and intellectual domains (ICAJE 1993, 383-386; DeFeo 2009, 57). Similarly, CBCT $尺$ embeds the cognitive and emotional dimensions through contemplation experience. For instance, witnessing the suffering of others correlates with how endearing those others are to us (Negi 2017, 24). Because we more easily identify those whom we appreciate, Module V attempts to elicit gratitude in practitioners. Informed by the IPP's principle of experience, I designed a drawing activity to help students recognize the interconnected factors that contribute to their life. I then led a Module V contemplation practice that fostered students' reflection on how their well-being depends on others. The activity and contemplation attempted to stimulate a direct experience of gratitude in students to enhance their affection toward people whom they would generally not consider. A year after our course, one student shared with me that they had developed the feeling of social warmth and a sense of responsibility toward the people they interacted with. These experiences were not based on a single practice session, but on cognitive changes from a ten-week cultivation period. This shows how both the IPP and $C B C T \circledast$ support experiential learning to synthesize intellect and emotion for character formation.

IPP's third element, reflection, instructs students how to examine their learning experiences for insights that will lead to action (ICAJE 1993, 386). CBCT®'s second level of learning, analytical meditation, supports the IPP's element of reflection through participants' reconsideration of their relationships. For example, because one generally feels compassionate toward those who are close to oneself, Module IV's practice tries to diminish the demarcation among friends, strangers, and adversaries. Participants meditate on how all people share humanity's common desire for well-being. ${ }^{7}$ While it was not easy, students gradually began to see the situations from the different perspective of their "adversaries." A student posted in our Facebook group:

Sometimes it's challenging to empathize with those people in our adversary category, but I've realized it does neither them nor I any good to dwell on the little things that cause this feeling but rather focus on the underlying fact that we both are in pursuit of happiness.

This comment demonstrates that CBCT® was effective for this student and exemplifies the IPP's reflection goal. Furthermore, the IPP's reflection element challenges teachers not to impose values, such as altruism. Therefore, I formulated questions that would deepen students' understanding and made my guided meditation invitational. This integrated pedagogical method attempted to motivate students to achieve the next IPP element, action.

Action has two aspects: Inward action refers to interior choices, such as changing a perspective; Outward action results when that new attitude is manifested (ICAJE 1993, 389-390). CBCT $®$ offers the IPP a systematic method for approaching both. For example, Module III aims to generate a "determination to emerge" in which practitioners decide to move beyond misleading and self-blaming thought patterns (Negi, 2017, 20). The following student's response indicates a shifting perspective, which can be seen as the IPP's “inward action.”

Through the practice of compassion towards ourselves we can break out of old thinking patterns ... I will try to stop myself from falling into the trap of self criticism [sic] and negative thinking ...

CBCT®'s final goal is to help practitioners embody a compassionate mindset beyond their personal concerns. The actions they may take based on this cultivated mentality parallel the IPP's area of “outward action." For instance, Module VI directs

\footnotetext{
6 For discussion on the potential pitfalls of meditation, see Compson, (2014). Brown University (2020) has training workshops about creating a safe environment for teaching meditation.

7 I asked my students to picture only "adversaries" they personally knew and for whom they felt only minor negative emotions. Stronger negative emotions could have been too intense at this early stage.
} 
participants to acknowledge others' pain and cultivate an urge to help the vulnerable. To make this practice relevant to their personal contexts, I integrated students' stated concerns for the indigent, immigrants, refugees, animals, and so forth, into our guided contemplation practice.

Both $C B C T \circledR$ and Jesuit education strive to cultivate this compassion. However, detecting students' moral growth is often challenging through regular academic assessments. Thus, ICAJE suggests that teachers use methods like journaling, selfevaluation, and voluntary service to measure their students' progress (1993, 390-391). Aligning with the IPP element of evaluation, my СВСТ® course used various strategies to measure students' whole-person development. First, I either had oneon-one or group discussions about issues that students encountered during their practice. Second, the students' Facebook comments allowed me to investigate to what extent students' perspectives had shifted based on their intellectual understanding and meditation practice. Third, I designed class activities to promote students' self-evaluation. For example, through "mindful listening," students practiced concentrating nonjudgmentally on their partner's concerns and summarizing what they heard. To evaluate my students' overall changes in ethical concerns and emotional health, I used three self-evaluated measurements, which students completed both before and after the course: the Compassionate Love for Humanity Scale (Sprecher and Fehr 2005), the UCLA Loneliness Scale (Russell, Peplau, and Cutrona 1980), and the Depression Anxiety and Stress Scale (Lovibond and Lovibond 1995). ${ }^{8}$ While there were some limitations for this pilot study, the results show positive correlations between my students' CBCT $R$ experience and their increase in compassion levels and emotional well-being. ${ }^{9}$ As ways to examine amorphous learning outcomes, like spiritual growth, are scarce (Lovette-Colyer 2014), my use of these scales gives educators some additional methods to actualize the IPP's evaluation element.

\section{Conclusion}

This study indicates that incorporating contemplative practice inspired by Buddhism into the IPP supports the Jesuit educational goal of caring for an individual's whole-person development and compassionate character formation. My students' course evaluations also demonstrate the effectiveness of this integration. They felt it improved their emotional well-being and empathy for others, and in the words of one student: "This class has truly helped me to become a happier and more compassionate person."

Based on this teaching project, I created the credited undergraduate course Buddhist Meditation and Practice, for which I adopted both the IPP and some aspects of $C B C T \circledast$. For example, in an essay, students needed to reflect on how their one-week mindful breathing practice differed from the practice described in Anapannasati Sutta (On the Full Awareness of Breathing), and on which concepts in neuroscientist Wendy Hasenkamp's (2013) “How to Focus a Wandering Mind” resonated with their personal contexts. Such an integration of pedagogical methods supports students' ability to synthesize their experiences with the readings so as to reach the higher level of cognitive work of constructing their own knowledge. ${ }^{10}$ While I have applied this combination in a Buddhist meditation class, it would be equally possible to connect the IPP with the principles of contemplation practice in other disciplines, such as in a Western religion class, a biology class, a class with a service component, a course on ethics, and so forth. This bridging will ideally encourage educators to further enhance students' learning by paying attention to their contexts, inspiring their affective experiences, deepening their understanding of subjects through reflection, and inducing their inner transformation through inspiring action or a shift of perspectives. Furthermore, including contemplation exercises with the IPP fits into the emerging discipline of contemplative studies (Komjathy 2018). ${ }^{11}$ More educators are integrating contemplation practices, such as mindfulness, into higher education (for example see, Barbezat and Bush 2014; Roth 2014; McGuire 2019). ${ }^{12}$ A further dialogue between Ignatian and contemplative pedagogies can be fruitful because the IPP and contemplative learning value students' development (for example, see Grace 2011, 116).

8 For those measurements, I conducted a paired samples two-tailed t-test.

9 These self-evaluations were only used as a reference for my teaching. The Institutional Review Board considered such usage and my CBCT® course to be a "quality improvement project." The results are restricted to my students and will not be necessarily applicable to other CBCT $®$ practitioners.

10 To address the level of cognitive work, I borrowed the concept of six-order thinking skills listed in the ThinkWell-LearnWell Diagram (Learnwell Projects 2020).

11 I acknowledge that teaching at a private university allowed me to lead my CBCT® teaching project and to include contemplation practice in my Buddhist Meditation and Practice course. It is more challenging to have such application in public universities (see Brown 2019 ).

12 Also, an increase of the applications of contemplation techniques across disciplines is demonstrated by eager participation in the annual summer workshop organized by the Association for Contemplative Mind in Higher Education at Smith College (personal participation in 2019). 
In conclusion, my incorporation of contemplative practice inspired by Buddhism into the IPP created a collaborative classroom that emphasized experiences in both the cognitive and affective dimensions, fostering ethical character formation as a result. Because achieving holistic growth is complex, educators would be well-served to merge multiple pedagogies. The IPP is an ideal candidate for teachers merging pedagogies. This study suggests that educators across disciplines can employ similar methods to my approach to build a rigorous, well-rounded learning environment.

\section{B I B LIOGRAPHY}

Barbezat, Daniel, and Mirabai Bush. 2014. Contemplative Practices in Higher Education:. Powerful Methods to Transform Teaching and Learning. San Francisco, CA: Jossey-Bass.

Brown, Candy Gunther. 2019. "Why I Do Not Use Contemplative Pedagogy in the Public University Classroom.” Spotlight on Teaching June 18, 2019. https://rsn.aarweb.org/spotlight-on/teaching/contemplative-pedagogy/ why-i-do-not-use-contemplative-pedagogy-public-university-classroom.

Brown University. 2020. “First Do No Harm: Meditation Safety Training Description.” The Clinical and Affective Neuroscience Laboratory. https://www.brown.edu/research/labs/britton/news-and-events/first-do-no-harmmeditation-safety-training-description.

Chien, Gloria I-Ling. 2016. “Examining the Blo sbyong Component in Thogs med bzang po's Collected Works.” Revued'Etudes Tibétaines 37: 48-68.

Compson, Jane. 2014. "Meditation, Trauma and Suffering in Silence: Raising Questions about How Meditation Is Taught and Practiced in Western Contexts in the Light of a Contemporary Trauma Resiliency Model." Contemporary Buddhism 15, no. 2: 274-297. https://doi.org/10.1080/14639947.2014.935264.

Crabtree, Robbin D., Joseph A. DeFeo, and Melissa M. Quan. 2012. "Feminist Pedagogy, the Ignatian Paradigm, and Service-Learning: Distinctive Roots, Common Objectives, and Intriguing Challenges." In Jesuit and Feminist Education: Intersections in Teaching and Learning for the Twenty-First Century, edited by Jocelyn M Boryczka and Elizabeth A. Petrino, 128-139. New York, NY: Fordham University Press.

DeFeo, Joseph A. 2009. “Old Wine in New Skin: Ignatian Pedagogy, Compatible with and Contributing to Jesuit Higher Education.” PhD diss., Fordham University. https://www.xavier.edu/jesuitresource/iesuit-a-z/documents/DefeoDissertation.pdf.

Desbordes, Gaëlle, Lobsang T. Negi, Thaddeus W. W. Pace, Alan B. Wallace, Charles L. Raison, and Eric L. Schwartz. 2012. "Effects of Mindful-Attention and Compassion Meditation Training on Amygdala Response to Emotional Stimuli in an Ordinary, Non-Meditative State." Frontiers in Human Neuroscience 6, no. 292: 1-15. https://www. frontiersin.org/articles/10.3389/fnhum.2012.00292/full.

Dodds, Sally, Thaddeus W. W. Pace, Melanie L. Bell, Mallorie Fiero, Lobsang T. Negi, Charles L. Raison, and Karen Weihs. 2015. "Feasibility of Cognitively-Based Compassion Training (CBCT) for Breast Cancer Survivors: A Randomized, Wait List Controlled Pilot Study.” Supportive Care in Cancer 23, no. 12: 1-10. https://doi. org/10.1007/s00520-015-2888-1.

Emory University. 2020 a. “CBCT® Compassion Training.” https://compassion.emory.edu/cbct-compassion-training/ index.html.

Emory University. 2020 b. “The Center for Contemplative Science and Compassion-Based Ethics.” http://compassion. emory.edu/about.html.

Gin, Deborah H.C., and Mark Chung Hearn. 2019 “Why You Do What You Do: The Power in Knowing and Naming Pedagogies." Teaching Theology and Religion 22, no. 1: 30-51. https://doi.org/10.1111/teth.12467. 
Grace, Fran. 2011. “Learning as a Path, Not a Goal: Contemplative Pedagogy-Its Principles and Practices.” Teaching Theology and Religion 14, no. 2: 99-124. https://doi.org/10.1111/i.1467-9647.2011.00689.x.

Hasenkamp, Wendy. 2013. “How to Focus a Wandering Mind.” Greater Good Magazine, July 17, 2013. https:// greatergood.berkeley.edu/article/item/how to focus a wandering mind.

Ignatius of Loyola, and George E. Ganss, S. J. 1992. The Spiritual Exercises of Saint Ignatius: A Translation and Commentary. St. Louis, MO: Institute of Jesuit Sources.

ICAJE (International Commission on the Apostolate of Jesuit Education).1986. "The Characteristics of Jesuit Education." In The Jesuit Ratio Studiorum: 40oth Anniversary Perspectives, edited by Vincent J. Duminuco, 161-230. New York, NY: Fordham University Press, 2000.

ICAJE (International Commission on the Apostolate of Jesuit Education).1993. "Ignatian pedagogy: A Practical Approach." In Ignatian Pedagogy: Classic and Contemporary Texts on Jesuit Education from St. Ignatius to Today, edited by José A. Mesa, 367-423. Chicago, IL: Loyola Press, A Jesuit Ministry, 2017.

Komjathy, Louis. 2018. Introducing Contemplative Studies. Hoboken, NJ: Wiley Blackwell.

Learnwell Projects. 2020. “Resources: Powerful Tools.” https://www.thelearnwellprojects.com/resources/.

Lovibond, Sydney H., and Peter F. Lovibond. 1995. "The Structure of Negative Emotional States: Comparison of the Depression Anxiety Stress Scales (DASS) with the Beck Depression and Anxiety Inventories." Behaviour Research and Therapy 33, no. 3: 335-343. https://doi.org/10.1016/0005-7967(94)00075-U.

Lovette-Colyer, Michael. 2014. “Cultivating Compassion: Rhetoric or Reality?” Journal of Catholic Higher Education 33, no. 2: $129-148$.

Mascaro, Jennifer S., James K. Rilling, Lobsang T. Negi, and Charles L. Raison. 2013. “Compassion Meditation Enhances Empathic Accuracy and Related Neural Activity.” Social Cognitive and Affective Neuroscience 8, no. 1: 48-55. https://doi.org/10.1093/scan/nssog5.

Mascaro, Jennifer S, Sean Kelley, Alana Darcher, Lobsang T. Negi, Carol Worthman, Andrew Miller, and Charles Raison. 2018. “Meditation Buffers Medical Student Compassion from the Deleterious Effects of Depression." The Journal of Positive Psychology 13, no. 2: 133-142. https://doi.org/10.1080/17439760.2016.1233348.

McGuire, Beverley. 2019. "Analogous activities: Tools for Thinking Comparatively in Religious Studies Courses.” Teaching Theology and Religion 22, no. 1: 114-126. https://doi.org/10.1111/teth.12478.

Negi, Lobsang T. 2017. “Cognitively-Based Compassion Training Manual-Prepared for Teacher Certification.” In CBCT: Cognitively-Based Compassion Training-Teacher Certification, Negi-Summer 2017, edited by Emory University, 1-68. Ann Arbor, MI: XanEdu Publishing, Inc.

Nhat Hanh, Thich, Annabel Laity, and Arnold Kotler. 1996. Breathe! You Are Alive: Sutra on the Full Awareness of Breathing. Berkeley, CA: Parallax Press.

Nowacek, Rebecca S., and Susan M. Mountin. 2012. "Reflection in Action: A Signature Ignatian Pedagogy for the 21st Century." In Exploring More Signature Pedagogies: Approaches to Teaching Disciplinary Habits of Mind, edited by Nancy L Chick, Aeron Haynie, and Regan A. R. Gurung, 129-142. Sterling, VA: Stylus Publishing.

Ozawa-de Silva, Brendan, Brooke Dodson-Lavelle, Charles L. Raison, and Lobsang T. Negi. 2012. “Compassion and Ethics: Scientific and Practical Approaches to the Cultivation of Compassion as a Foundation for Ethical Subjectivity and Well-Being." Journal of Healthcare, Science and the Humanities 2, no. 1: 145-161.

$72 \quad$ 2021; 2:1 67-74 The Wabash Center Journal on Teaching

This work is licensed under a Creative Commons Attribution-NonCommercial 4.0 International License 
Pace, Thaddeus W. W., Lobsang T. Negi, Brooke Donaldson-Lavelle, Brendan Ozawa-de Silva, Sheethal D. Reddy, Steven P. Cole, Linda W. Craighead, and Charles L. Raison. 2012. "Cognitively-Based Compassion Training Reduces Peripheral Inflammation in Adolescents in Foster Care with High Rates of Early Life Adversity." BMC Complementary and Alternative Medicine 12 (Suppl 1): 175. https://doi.org/10.1186/1472-6882-12-S1-P175.

Pace, Thaddeus W. W., Lobsang T. Negi, Daniel D. Adame, Steven P. Cole, Teresa I. Sivilli, Timothy D. Brown, Michael J. Issa, and Charles L. Raison. 2009. "Effect of Compassion Meditation on Neuroendocrine, Innate Immune and Behavioral Responses to Psychosocial Stress." Psychoneuroendocrinology 34, no. 1: 87-98. https://doi. org/10.1016/i.psyneuen.2008.08.011.

Rashedi, Roxanne, Thomas G. Plante, and Erin S. Callister. 2015. “Compassion Development in Higher Education.” Journal of Psychology and Theology 43, no. 2: 131-139. https://doi.org/10.1177/009164711504300205.

Reddy, Sheethal D., Lobsang T. Negi, Brooke Dodson-Lavelle, Brendan Ozawa-de Silva, Thaddeus W. W Pace, Steven P. Cole, Charles L. Raison, and Linda W. Craighead. 2013. "Cognitive-Based Compassion Training: A Promising Prevention Strategy for At-Risk Adolescents.” Journal of Child and Family Studies 22, no. 2: 219-230. https:// doi. org/10.1007/s10826-012-9571-7.

Roth, Harold. 2014. “A Pedagogy for the New Field of Contemplative Studies.” In Contemplative Learning and Inquiry across Disciplines, edited by Olen Gunnlaugson, Edward W Sarath, Charles Scott, and Heesoon Bai, 97-115. Albany, NY: State University of New York Press.

Russell, Dan, Letitia A. Peplau, and Carolyn E. Cutrona. 1980. “The Revised UCLA Loneliness Scale: Concurrent and Discriminant Validity Evidence." Journal of Personality and Social Psychology 39, no. 3: 472-480. https://doi. org/10.1037/0022-3514.39.3.472.

Sprecher, Susan, and Beverley Fehr. 2005. “Compassionate Love for Close Others and Humanity." Journal of Social and Personal Relationships 22, no. 5: 629-651. https://doi.org/10.1177/0265407505056439.

Van Hise, Joan, and Dawn W. Massey. 2010. "Applying the Ignatian Pedagogical Paradigm to the Creation of an Accounting Ethics Course." Journal of Business Ethics 96 (Spring): 453-465. https://doi.org/10.1007/s10551-0100477-2.

\section{ABOUT THE AUTHOR}

Dr. Gloria I-Ling Chien is an Assistant Professor who teaches Buddhism and Asian religions in the Religious Studies Department at Gonzaga University. She is also a certified instructor in Cognitively-Based Compassion Training ${ }^{\circledR}$. 
